JURNAL OSEANOGRAFI. Volume 4, Nomor 1, Tahun 2015, Halaman 100 - 108

Online di : http://ejournal-s1.undip.ac.id/index.php/jose

\title{
Analisis Dampak Gelombang Tinggi Pada Musim Barat Terhadap Penggunaan Lahan Pesisir di Kabupaten Rembang, Provinsi Jawa Tengah
}

\author{
Akhmad Hanan, Agus Anugroho DS, Muhammad Helmi*) \\ Program Studi Oseanografi, Jurusan Ilmu Kelautan, \\ Fakultas Perikanan dan Ilmu Kelautan, Semarang \\ muhammadhelmi69@gmail.com
}

\begin{abstract}
Abstrak
Kawasan pesisir Kabupaten Rembang adalah daerah yang terletak di pantai utara Pulau Jawa dan berbatasan langsung dengan Laut Jawa dimana sangat rawan pengaruh gelombang tinggi yang biasa terjadi pada musim barat yang berdampak terhadap penggunaan lahanpesisir. Tujuan penelitian ini adalah mengkaji dampak gelombang tinggi pada musim barat tersebut terhadap penggunaan lahan. Metode yang digunakan dalam penelitian ini menggunakan analisis data Satelit Altimetri Saral AltiKa dan Cryosat tahun 2009 - 2014 yang menghasilkan komponen gelombang. Untuk analisis data penggunaan lahan menggunakan analisis data satelit Landsat 8. Berdasarkan hasil wilayah pesisir Kabupaten Rembang yang terkena dampak gelombang tinggi pada musim barat dengan tinggi gelombang mencapai 2,24 meter adalah wilayah pesisir Kecamatan Kaliori dan Kecamatan Sluke. Penggunaan lahan yang terkena dampak gelombang tinggi di wilayah tersebut adalah tambak 149,7 Ha, lahan pertanian 34,59 Ha, permukiman 74,6 Ha dan mangrove 2,1 Ha. Wilayah yang terkena dampak gelombang pada musim barat kategori sedang adalah di wilayah Kecamatan Rembang dan sebagian wilayah Kecamatan Lasem luas penggunaan lahan sebesar 271,6 Ha. Sedangkan di wilayah Kecamatan Kragan dan Kecamatan Sarang dampak gelombang tinggi terhadap penggunaan lahan negatif.
\end{abstract}

Kata kunci: gelombang tinggi, musim barat, penggunaan lahan

\begin{abstract}
The coastal areaof RembangDistrict isan area locatedon the north coastof Javaand directly adjacent tothe Java Seais veryvulnerable fromthe influencewhich thehighwavesthat are common inwest monsoonaffectingcoastalland use. The purposeof thisstudyis to assessthe impact ofhighwavesonthewestseasonon land use. The method usedin this study usingsatellitealtimetrydata analysisSaralAltiKaandCryosatyears2009 - 2014whichresulted ina wavecomponents. Forland use dataanalysisusingLandsat8 satellite dataanalysis.Based onthe results ofthe coastal areasaffectedRembanghigh wavesonthe westseasonwithhighwaves reaching2.24metersis thecoastalregionofKalioriSubdistrict and SlukeSubdistrict. The use ofthe land affected bythe highwavesin the regionis149.7hapond, 34.59hectaresof agricultural land, settlements74.6haand2.1haof mangroves. The region affected bythe wavesonthe westseasoncategorybeingisin the Lasemsubdistrictvastmajorityof land useamounted to271.6ha. Whilein the Kragansubdistrictand Sarang subdistrict arenesthighwave impacton land useis negative.
\end{abstract}

Keywords: high waves, west monsoon, landuse

\section{Pendahuluan}

Kawasan pesisir pantai merupakan daerah yang masih mendapat pengaruh laut seperti gelombang, arus maupun pasang surut air laut (Triatmodjo, 1999). Sebagian besar kawasan pesisir merupakan daerah yang potensial dalam pengembangan kawasan.Kabupaten Rembang adalah daerah yang terletak di pantai Utara Pulau Jawa. Kabupaten Rembang memiliki luas $1014,08 \mathrm{~km}^{2}$ dengan topografi yaitu daerah pantai, dataran rendah, dataran tinggi dan pegunungan, dengan jenis tanah terdiri atas kandungan Mediterial, Grumosal, Aluvial, Andosal dan Regasal. Garis pantai terletak di sisi bagian utara yang berbatasan langsung dengan perairan Laut Jawa (BPS Kabupaten Rembang, 2012). Kawasan pesisir Kabupaten Rembang menurut 
BNPB (2011), merupakan salah satu kawasan yang memiliki indeks rawan bencana (hazard) gelombang tinggi dan abrasi.

Tingginya gelombang laut dan angin yang berhembus sangat kencang yang biasa terjadi pada saat musim barat dapat memberikan dampak yang signifikan bagi masyarakat nelayan. Mereka tidak bisa melaut untuk mencari ikan dan terpaksa akan mempengaruhi perekonomian. Hal ini diakibatkan karena cuaca saat musim barat yang ekstrim dan tidak bersahabat (Suprapto, 2011).

Berdasarkan laporan BPBD Jawa Tengah (2013), bulan Januari 2013 memasuki musim barat gelombang setinggi kurang lebih 1,5 - 2 meter melanda sebagian besar kawasan pesisir Kabupaten Rembang. Sebuah kapal tongkang yang sebelumnya membongkar muatan batubara di Pembangkit Listrik Tenaga Uap (PLTU) Sluke terdampar di pesisir Kecamatan Sluke, Kabupaten Rembang. Terjangan gelombang tersebut mengakibatkan pula lumpuhnya aktivitas nelayan dan abrasi di sepanjang pesisir pantai Kecamatan Sluke.

Permasalahan yang sering terjadi di wilayah pesisir Kabupaten Rembang yang menjadi lokasi penelitian saat ini adalah ketersediaan data gelombang yang sangat minim dan terbatas. Sehingga untuk menganalisis dampak gelombang tinggi pada musim barat terutama dampaknya terhadap penggunaan lahan di kawasan pesisir selama ini masih sangat sulit dilakukan. Berdasarkan permasalahan di pesisir Kabupaten Rembang maka penelitian tentang analisis dampak gelombang tinggi pada musim barat terhadap penggunaan lahan diperlukan untuk menghasilkan gambaran mengenai daerah gelombang tinggi saat musim barat dan dampaknya terhadap penggunaan lahan di wilayah pesisir Kabupaten Rembang.

Tujuan penelitian ini adalah mengetahui karakteristik gelombang tinggi musim barat serta dampaknya terhadap penggunaan lahan pesisir di Kabupaten Rembang, Provinsi Jawa Tengah. Hasil penelitian ini diharapkan memberikan informasi mengenai tinggi gelombang laut saat musim barat dan dampak yang ditimbulkannya terhadap penggunaan lahan di kawasan pesisir Kabupaten Rembang, Provinsi Jawa Tengah.

\section{Materi dan Metode}

Lokasi penelitian di daerah pesisir Kabupaten Rembang Provinsi Jawa Tengah. Menurut kedudukan geografis posisi lintang terletak antara $111^{\circ} 00^{\prime}-111^{0} 30^{\prime} \mathrm{BT}$ dan $6^{0} 30^{\prime}-7^{\circ} 00^{\prime} \mathrm{LS}$. Adapun lokasi penelitian terdiri atas 6 kecamatan di wilayah pesisir Kabupaten Rembang, yaitu: Kecamatan Kaliori, Kecamatan Rembang, Kecamatan Lasem, Kecamatan Sluke, Kecamatan Kragan, dan Kecamatan Sarang. Penelitian ini dilakukan pada bulan November 2013 sampai Maret 2014.

Metode penelitian yang digunakan dalam penelitian ini adalah studi kasus, menurut Hadi (2004), penelitian studi kasus adalah penelitian tentang suatu kasus secara mendalam yang berlaku pada waktu, tempat dan populasi yang terbatas, sehingga memberikan gambaran tentang situasi dan kondisi secara lokal dan hasilnya tidak dapat digeneralisasi atau di samakan untuk tempat yang berbeda. Metode analisis data yang digunakan dalam penelitian ini adalah metode analisis data satelit Altimetri. Dalam hal ini yang akan dilihat adalah variasi temporal komponen statistik bulanan selama periode musim barat berupa tinggi gelombang signifikan, dan kecepatan angin.

Satelit altimetri melakukan pengamatan terhadap muka laut dengan cara mengukur jarak satelit tersebut ke permukaan laut. Jarak satelit ke bidang ellipsoid dan jarak satelit ke pusat bumi. Altimeter mentransmisikan pulsa singkat radiasi gelombang mikro dengan daya tertentu terhadap permukaan laut. Pulsa tersebut kemudian berinteraksi dengan permukaan laut yang kasar dan sebagiannya lagi terpantul kembali ke altimeter (Fu dan Cazaneve, 2001). Secara umum prinsip pengukuran satelit altimetri dapat dilihat pada Gambar 1. 


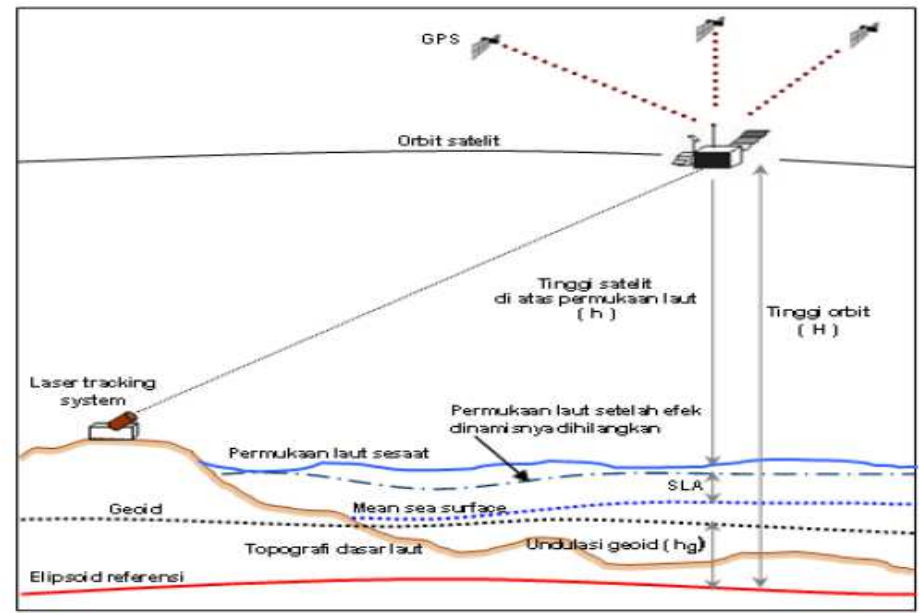

Gambar 1. Prinsip Dasar Pengukuran Satelit Altimetri (Fu dan Cazenave, 2001).

Jarak R dari satelit ke muka air laut rerata diperkirakan dari waktu bolak - balik satelit merekam, dan ditentukan dengan rumus:

$$
R=\square-\sum_{j} \Delta R_{j}
$$

Data primer yang diperlukan untuk mendukung penelitian ini adalah Data satelit Altimetri multimisi (Saral AltiKa dan Cryosat), wilayah Laut Jawa khususnya di perairan Rembang perekaman time series pada musim barat (bulan Desember - Februari) selama 5 tahun dari tahun 2009 hingga tahun 2014. Data citra satelit Landsat 8 perekaman tahun 2014 untuk mengetahui bentuk - bentuk penggunaan lahan kawasan pesisir, serta garis pantai dan data hasil verifikasi di lapangan (real world) yang meliputi data kordinat daerah penelitian, data penggunaan lahan data hasil pengukuran tinggi gelombang, serta dokumentasi lapangan.

Data sekunder yang diperlukan untuk mendukung penelitian ini terdiri dari data spasial yang umumnya berupa peta-peta tematik dan data statistik yaitu Peta Rupabumi (RBI) digital Kabupaten Rembang skala 1: 250.000 publikasi BIG tahun 2007 yang digunakan untuk proses koreksi pada citra satelit. Peta Bathymetri (Kedalaman Laut) skala 1:250.000 publikasi Dishidros TNI - AL pada tahun 2012 yang digunakan untuk overlay dengan data spasial gelombang laut dan kedalaman laut dan data demografi Kabupaten Rembang tahun 2013, publikasi Badan Pusat Statistik (BPS) Kabupaten Rembang.

Data karakteristik gelombang yang didapat seperti tinggi dan periode, dianalisis dengan menggunakan penentuan gelombang representatif menurut Triatmodjo (1999) sebagai berikut:

$$
\begin{aligned}
\mathrm{n} & =33,3 \% \mathrm{x} \text { jumlah data ....(2) } \\
\mathrm{Hs} & =\frac{H_{1}+H_{2}+\ldots+H_{n}}{n} \ldots \ldots \ldots \ldots \ldots .(3) \\
\mathrm{Ts} & =\frac{T_{1}+T_{2}+\ldots+T_{n}}{n} \ldots \ldots \ldots \ldots \ldots . . .(4)
\end{aligned}
$$

Untuk memperoleh daerah yang terkena dampak tinggi gelombang maka ditentukan beberapa parameter kriteria diantaranya adalah ketinggian daratan, jarak garis pantai, bentuk garis pantai, tinggi gelombang dan luas penggunaan lahan. Semua parameter tersebut kemudian memberikan bobot sesuai dengan besarnya pengaruh terhadap gelombang tinggi. Dalam penentuan daerah penggunaan lahan terkena dampak gelombang tinggi, dilakukan dengan melaksanakan metode tumpang susun (overlay method) dan permodelan data.

Survei pada studi ini dilakukan dalam bentuk verifikasi lapangan menggunakan metode Purposive Sampling yaitu menentukan lokasi pengambilan sampel berdasarkan pertimbanganpertimbangan tertentu (Hadi, 1993). 
Verifikasi lapangan untuk melakukan koreksi hasil pemetaan yang telah dilakukan menggunakan penginderaan jauh. Survei yang dilakukan pada penelitian ini adalah Survei untuk verifikasi hasil pemetaan penggunaan lahan dan pengukuran tinggi gelombang lautGambar 2 . .

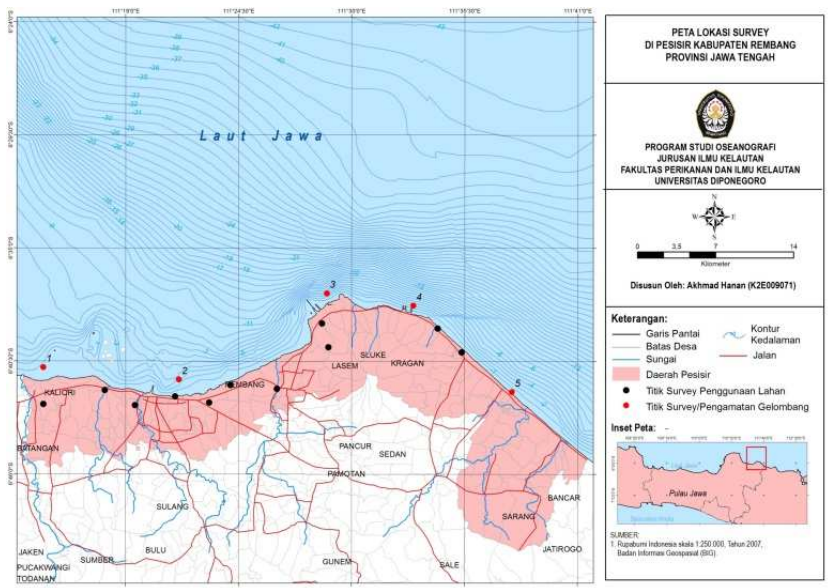

Gambar 2. Lokasi Survey lapangan.

\section{Hasil Dan Pembahasan}

\section{Tinggi Gelombang dan Angin Laut}

Berdasarkan hasil analisis kondisi karakteristik tinggi gelombang $(H)$ data satelit Altimetri di atas pada musim barat selama lima tahun dari Tahun 2009 hingga Tahun 2014, didapatkan hasil bahwa tinggi gelombang maksimum (Hmaks) tertinggi sebesar 2,494 meter yang terjadi pada periode bulan Desember 2012 - Februari 2013 pada tanggal 13 Janua ri 2013. Tinggi gelombang signifikan (Hs) tertinggi sebesar 1,169 meter pada periode musim barat bulan Desember 2010 - Februari 2011. Tinggi gelombang minimum (Hmin) sebesar 0,129 meter pada periode musim barat bulan Desember 2009 - Februari 2010. Perbandingan karakteristik tinggi gelombang dalam bentuk grafik disajikan dalam Gambar 3. Peta hasil model spasial gelombang satelit Altimetri ditunjukkan pada Gambar 4.

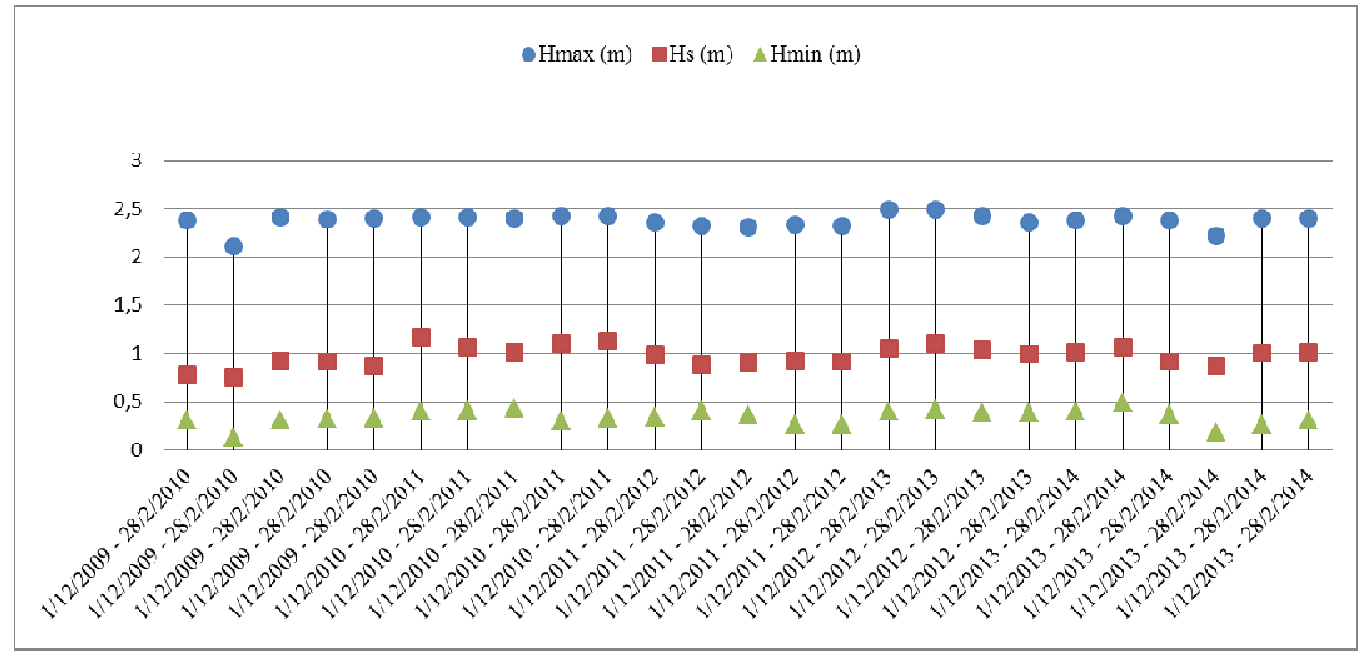

Gambar 3. Grafik Tinggi Gelombang Musim Barat Hasil

Pengamatan Satelit Altimetri (Tahun 2009 - 2014). 


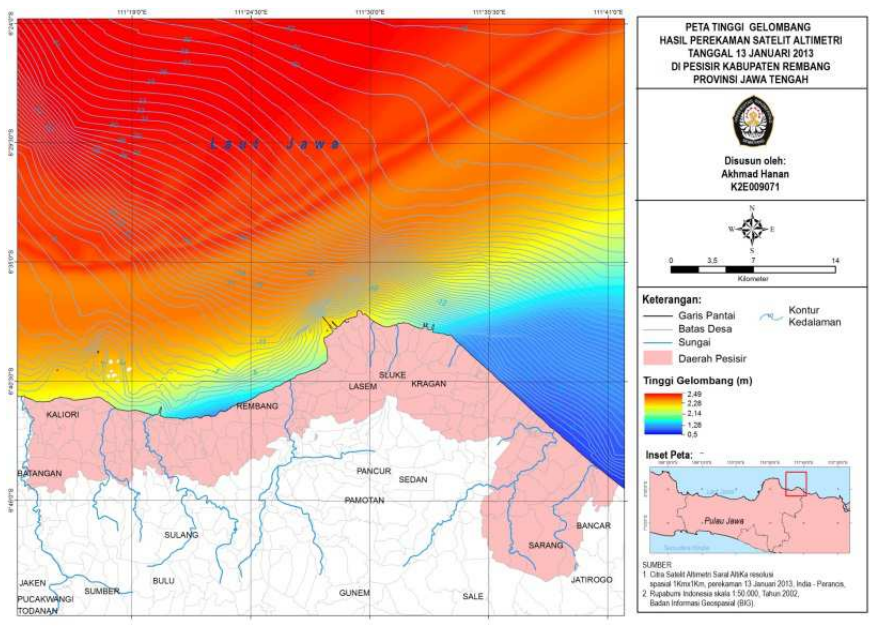

Gambar 4.Peta Tinggi Gelombang Hasil Analisis Data Satelit Altimetri pada Tanggal 13 Januari 2013Overlay dengan Kontur Kedalaman di Perairan Kabupaten Rembang.

Berdasarkan peta gelombang hasil pemodelan spasial tinggi gelombang laut gambar 4 diatas menunjukkan bahwa tinggi gelombang mencapai 2,26 meter hingga ke perairan kedalaman 3 meter dekat pesisir Kecamatan Sluke. Tinggi gelombang terendah di wilayah perairan Kecamatan Sarang dan Kragan yaitu 0,55 meter. Di wilayah perairan Kecamatan Rembang dan Lasem tinggi gelombang mencapai hampir 2 meter. Wilayah perairan Kecamatan Kaliori tinggi gelombang mencapai 2 meter lebih.

Dari hasil pengamatan data Satelit Saral AltiKa dan Cryosat, dominan arah angin pada musim barat periode Tahun 2009 - 2014 adalah dari arah barat laut (BL). Dengan kisaran kecepatan angin dominan antara 12 - 21 knots. Mawar angin ditunjukkan pad Gambar 5.

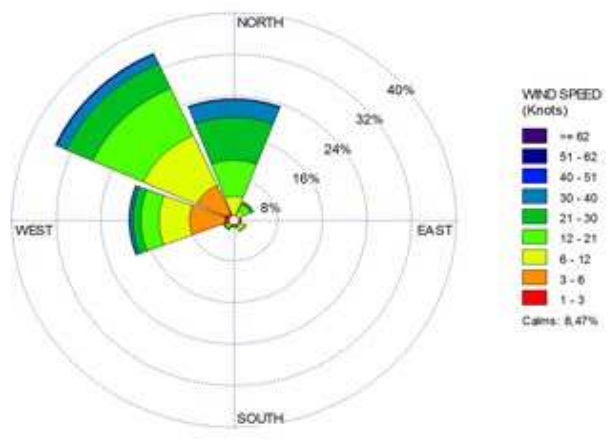

Gambar 5. Hasil Pengamatan Angin Laut oleh Satelit Altimetri Pada Musim Barat Selama Lima Tahun (2009 - 2014).

\section{Verifikasi Data Gelombang Pengukuran dan Data Satelit}

Hasil pengukuran data lapangan yang dilakukan pada tanggal 30 November - 2 Desember 2013 digunakan untuk verifikasi data satelit Altimetri gelombang laut pada waktu yang sama dengan waktu pengukuran data gelombang lapangan. Grafik validitas tinggi gelombang ditunjukkan pada Gambar 6. Tabel nilai verifikasi data hasil gelombang lapangan dan data gelombang satelit disajikan pada Tabel 1. 
Tabel 1. Verifikasi Data Hasil Gelombang Lapangan dan Data Satelit

\begin{tabular}{llccc}
\hline No. & \multicolumn{1}{c}{ Data } & Hs (Meter) & $\begin{array}{c}\text { MRE(Mean } \\
\text { Relative } \\
\text { Error) }\end{array}$ & $\begin{array}{c}\text { Selisih } \\
\text { nilai } \\
\text { (meter) }\end{array}$ \\
\hline 1. & Gelombang Lapangan & 0,63 & 11,26760563 & 0,08 \\
2. & Gelombang Satelit & 0,710 & & \\
\hline
\end{tabular}

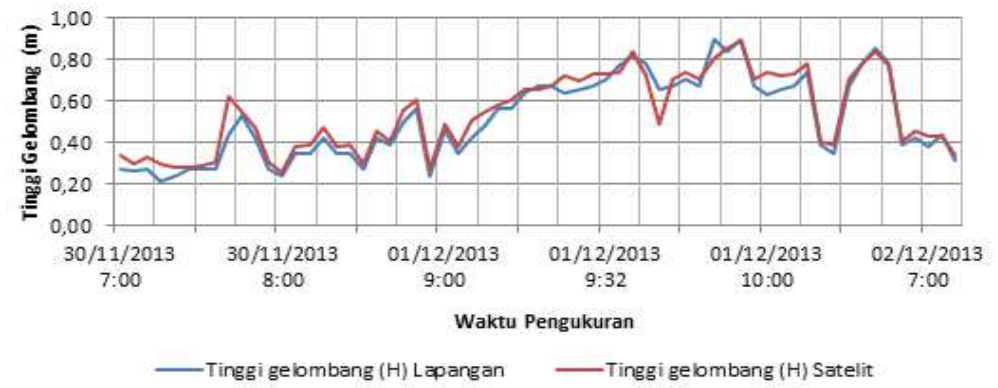

Gambar 6. GrafikValiditas Hasil Pengamatan Tinggi Gelombang Menggunakan Satelit Altimetri dengan Data Pengukuran Lapangan

Hasil verifikasi pengolahan data gelombang lapangan dengan data gelombang hasil analisis data satelit Altimetri yang diambil tinggi gelombang signifikan (Hs) pada waktu yang bersamaan menunjukkan bahwa nilai mean relative error (MRE) untuk tinggi gelombang laut adalah sebesar $11,26 \%$, dengan selisih nilai sebesar 0,08 meter.Tingkat validitas data gelombang satelit altimetri kurang dari 50\% sehingga dapat digunakan sebagai inputan untuk perhitungan dan analisis selanjutnya.

\section{Sebaran Penggunaan Lahan Pesisir}

Data penggunaan lahan didapat dari hasil digitasi Peta Rupabumi Indonesia daerah di Kabupaten Rembang Tahun 2001, kemudian melakukan updating dengan overlay citra Landsat 8 perekaman tahun 2014 yang memiliki resolusi 15 meter.Penggunaan lahan pesisir di Kabupaten Rembang terdiri atas permukiman, sawah/lahan pertanian, tambak, perkebunan, semak belukar, mangrove dan hutan alam. Peta sebaran penggunaan lahan ditunjukkan pada Gambar 7.

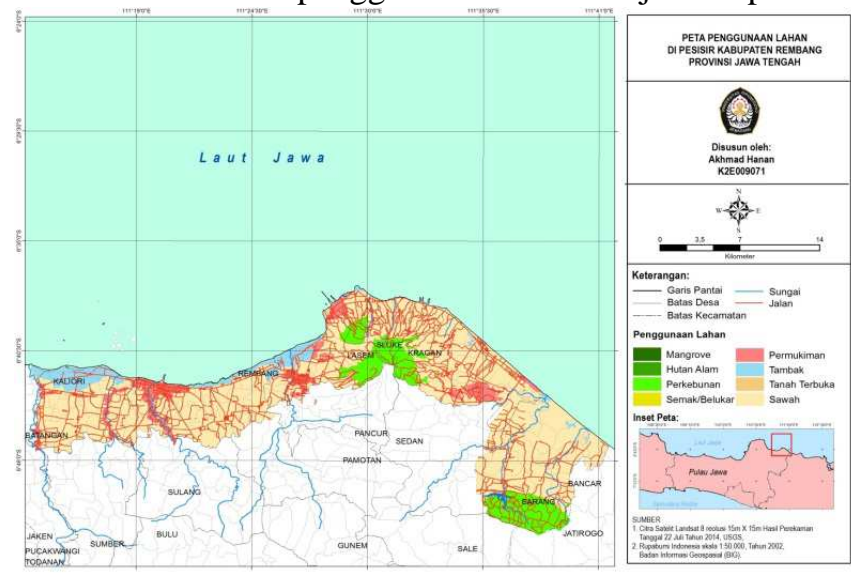

Gambar 7.Peta Penggunaan Lahan di Pesisir Kabupaten Rembang 
Luas penggunan lahan untuk kawasan permukiman di pesisir Kabupaten Rembang total adalah seluas 783,5 ha, tanah terbuka 209,4 ha, sawah atau lahan pertanian 563,1 ha perkebunan 17,4 ha, tambak 704,3 ha, semak belukar 0,4 ha, kawasan hutan alam 160 Hadan mangrove 19,1 ha.

\section{Wilayah Terdampak Gelombang Tinggi}

Penentuan wilayah yang terkena dampak tinggi gelombang maka ditentukan beberapa parameter kriteria diantaranya ketinggian daratan, jarak danbentuk garis pantai, tinggi gelombang dan luas penggunaan lahan. Dalam penentuan daerah penggunaan lahan terkena dampak gelombang tinggi, dilakukan dengan melaksanakan overlay.

Berdasarkan pengolahan data titik tinggi (Gambar 8), didapatkan hasil berupa peta ketinggian daerah pesisir Kabupaten Rembang dimana terdapat daratan yang sangat rendah dengan ketinggian kurang dari 10 meter yaitu di hampir seluruh pesisir Kabupaten Rembang. namun terdapat pula daratan yang mempunyai ketinggian 10 - 30 meter yaitu pada bagian pesisir tengah Kecamatan Sluke. Hasil klasifikasi bentuk garis pantai (Gambar 9),, didapatkan hasil berupa peta bentuk garis pantai daerah pesisir Kabupaten Rembang dimana terdapat bentuk garis pantai berteluk - lurus, tanjung dan lurus di kawasan pesisir Kabupaten Rembang. Kecamatan Kaliori, Kecamatan Rembang, dan Kecamatan Lasem termasuk kategori wilayah pesisir yang memiliki bentuk garis pantai berteluk - lurus. Kecamatan Sluke memiliki bentuk garis pantai bertanjung. Kecamatan Kragan dan Kecamatan Sarang memiliki bentuk garis pantai lurus.

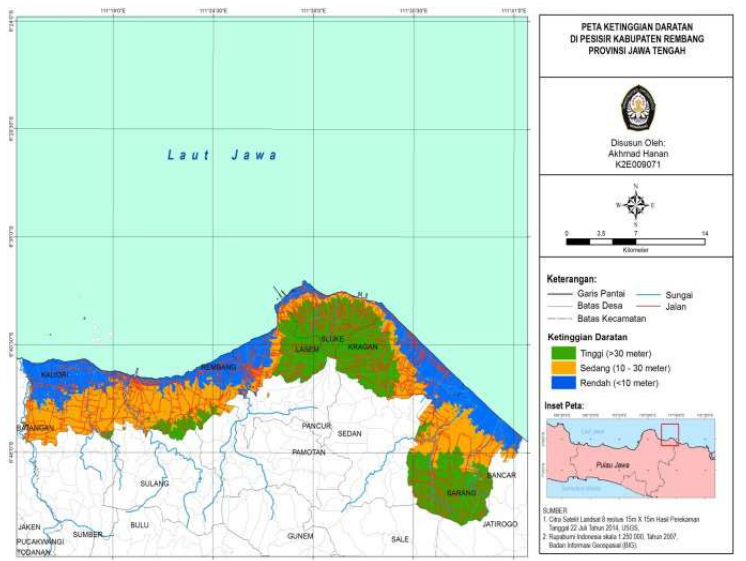

Gambar 8. Peta Ketinggian Daratan
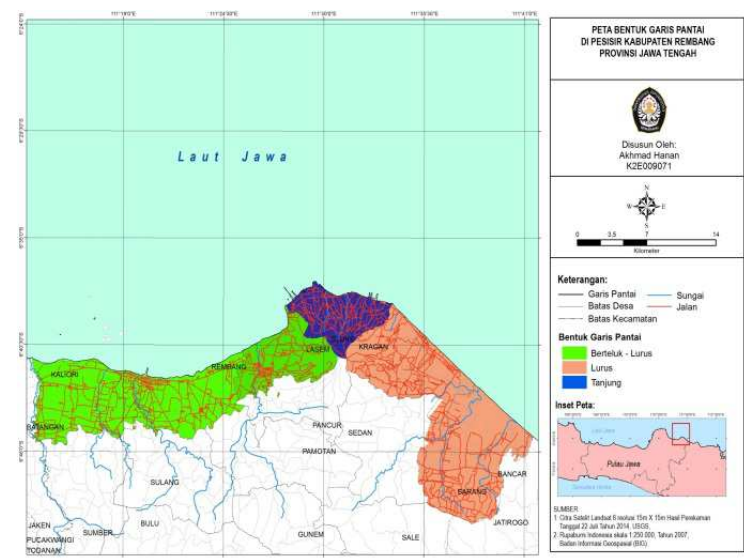

Gambar 9. Peta Bentuk Garis Pantai.

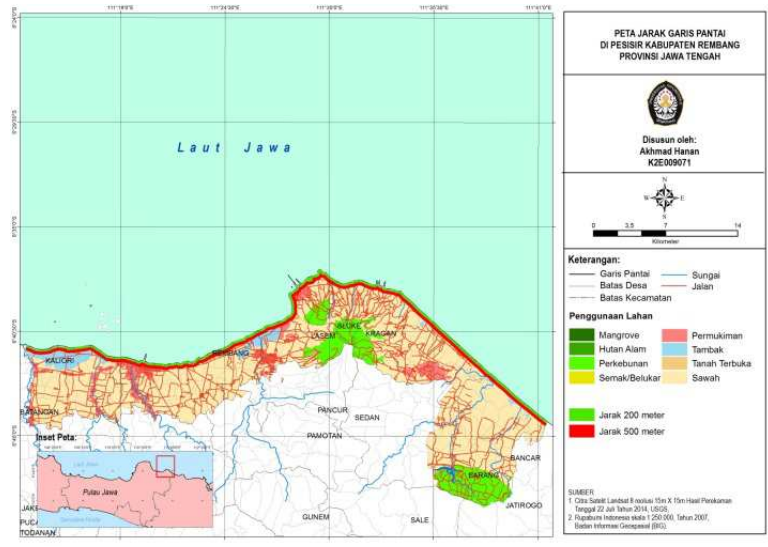

Gambar 10. Peta Jarak Garis Pantai. 
Hasil pengelompokan garis pantai (Gambar 10) menunjukkan bahwa kawasan pesisir Kabupaten Rembang berjarak 200 meter dari garis pantai memiliki luas lahan 258,12 ha. Sedangkan untuk kawasan pesisir Kabupaten Rembang yang berjarak 500 meter dari garis pantai memiliki luas lahan 460,32 ha. Sebagian besar wilayah pesisir Kabupaten Rembang merupakan wilayah datar dan landai. Peta dampak gelombang tinggi terhadap penggunaan lahan ditunjukkan pada Gambar 11. Tabel dampak gelombang tinggi pada musim barat terhadap penggunaan lahan dapat dilihat pada Tabel 2.

Tabel 2. Dampak Gelombang Tinggi Musim Barat Terhadap Penggunaan Lahan

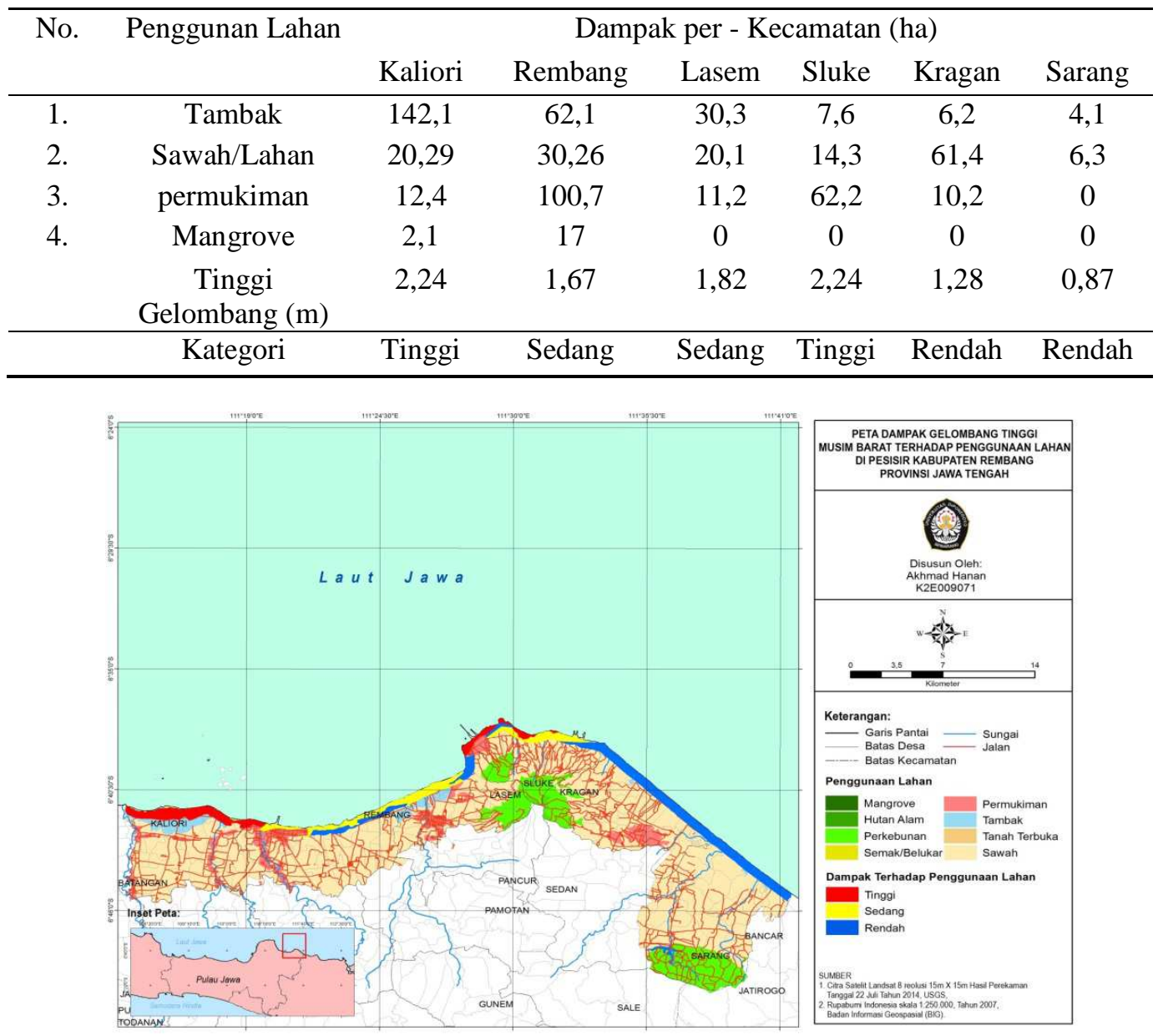

Gambar 11. Dampak Gelombang Tinggi pada Musim Barat Terhadap Penggunaan Lahan.

Terdapat tiga kriteria wilayah pesisir yang terkena dampak gelombang tinggi musim barat. Wilayah dengan kategori tinggi terkena dampak penggunaan lahan terdapat di wilayah Kecamatan Kaliori dengan luas lahan terdiri atas permukiman 12,4 Ha, Tambak 142,1 Ha, lahan pertanian 20,29 $\mathrm{Ha}$, dan mangrove 2,1 Ha. Wilayah Kecamatan Sluke dengan luas lahan terdiri atas tambak 7,6 Ha, permukiman 62,2 Ha dan lahan pertanian 14,3 Ha.

Wilayah kategori sedang terkena dampak gelombang tinggi terdapat di wilayah pesisir Kecamatan Rembang dan sebagian Kecamatan Lasem dengan luas penggunaan lahan sebesar 271,6 Ha. Wilayah kategori rendah terkena dampak gelombang tinggi pada musim barat adalah wilayah pesisir Kecamatan Kragan dan Kecamatan Sarang.

\section{Kesimpulan}


Berdasarkan hasil analisis satelit Saral AltiKa dan Cryosat Tahun 2009 - 2014, pada musim barat (Desember - Pebruari) gelombang tinggi gelombang maksimum (Hmaks) terdapat pada musim barat periode bulan Desember 2012 hingga Februari 2013 dengan tinggi gelombang mencapai 2,49 meter yang terjadi pada tanggal 13 Januari 2013.

Wilayah pesisir Kabupaten Rembang yang terkena dampak gelombang tinggi pada musim barat maksimum adalah wilayah pesisir Kecamatan Kaliori dan Kecamatan Sluke. Penggunaan lahan yang terkena dampak gelombang tinggi sebesar 2,24 $\mathrm{m}$ di wilayah tersebut adalah tambak 149,7 Ha, lahan pertanian 34,59 $\mathrm{Ha}$, permukiman 74,6 Ha dan mangrove 2,1 Ha. Wilayah yang terkena dampak gelombang pada musim barat kategori sedang adalah di wilayah Kecamatan Rembang dan sebagian wilayah Kecamatan Lasem luas penggunaan lahan sebesar 271,6 Ha. Sedangkan di wilayah Kecamatan Kragan dan Kecamatan Sarang dampak gelombang tinggi terhadap penggunaan lahan negatif. Semakin besar tinggi gelombang semakin mempengaruhi perubahan garis pantai, penggunaan lahan dan kondisi geomorfologi kawasan pesisir tersebut.

\section{Ucapan Terimakasih}

Terimakasih kepada Dinas Kelautan (DKP) Kabupaten Rembang dan Badan Penanggulangan Bencana Daerah Provinsi Jawa Tengah atas bantuan serta izin yang telah diberikan selama penelitian berlangsung.

\section{Daftar Pustaka}

Badan Nasional Penanggulangan Bencana (BNPB). 2011. Indeks Rawan Bencana Indonesia. Jakarta.

Badan Penanggulangan Bencana Daerah (BPBD). 2013. Laporan Informasi Kebencanaan Bulanan Teraktual: Edisi Januari 2013. BPBD Jawa Tengah. Semarang.

Badan Pusat Statistik Kabupaten Rembang. 2012. Rembang Dalam Angka Tahun 2012. BPS Kabupaten Rembang. Rembang.

Cazeneve, A dan L, Fu. 2001. Satelite Altimetry and Earth Sciences, A Handbook of Techniques and Applications. Academic Press. USA.

Hadi, S. 2004. Metodologi Research. Jilid 1. Yogyakarta; Andi, 150 hlm.

Suprapto. 2011. Statistik Pemodelan Bencana Banjir Indonesia (Kejadian 2002 - 2010). BNPB. Jakarta.

Triatmodjo, B. 1999. Teknik Pantai. Yogyakarta: Betta Offset. 